\title{
Village day in diaspora
}

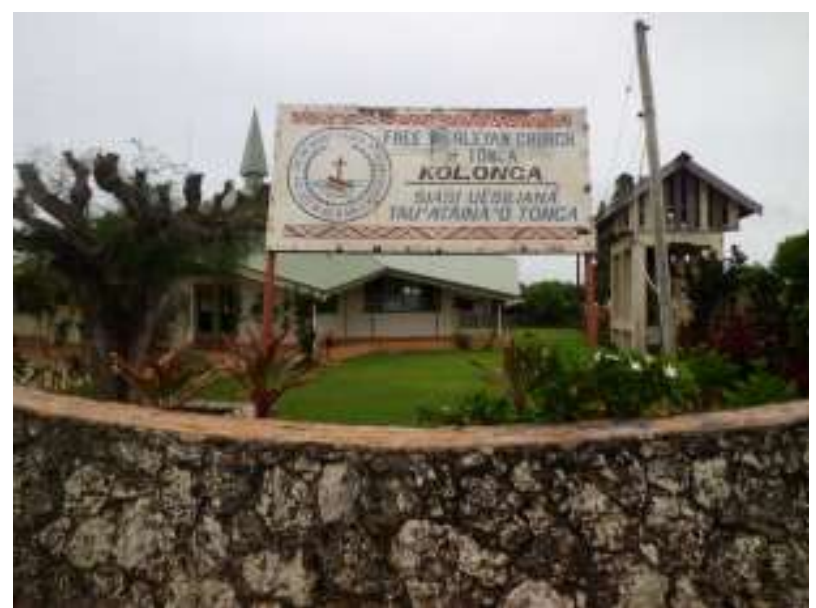

Photograph Credit: Teena Brown Pulu

On New Zealand Labour Day, October 26th 2015, affiliates of a rural farming village in Tonga residing in Auckland held a feast for Kolonga Day. It was convened at the Otahuhu Library, Pool, and Leisure Centre with over one thousand people in attendance. The centre is an Auckland Council hub for the diverse communities of Otahuhu to use. Why celebrate a Tongan village in New Zealand?

Commemorating communities in Tonga by hosting village days overseas is an invented cultural practice in diaspora. In developed countries where Tongans have migrated to - New Zealand, Australia, and the United States - village days have taken off as the instigator of sub-nationalism.

Sub-nationalism is a social phenomenon transpiring at the community level. It is distinguishable from Tongan nationalism, a weightier and widespread model of patriotism, which applauds the South Pacific Kingdom as the cornerstone

Teena Brown Pulu is a Senior Lecturer in the Faculty of Maori and Indigenous Development at Auckland University of Technology. 
of its motto, God and Tonga are my inheritance. Contrastingly, sub-nationalism evokes the individuality and unique characteristics that a village is remembered for.

Rampant Tongan nationalism is reproduced by manoeuvring history from above and below. The current monarch, King Tupou VI, appeals to loyalists and royalists, while the country's rugby team, 'Ikale Tahi, charms all classes of citizens and expatriates. Therefore, it seems remarkable that amidst the pomp of Tongan patriotism, overseas settlements have diverged to put village loyalties on parade.

How do village allegiances fill a cultural void that the extensiveness of Tongan nationalism - devotion to God, King, and country - cannot? Is it the fact that some overseas Tongans maintain homes and properties in their villages of ancestral descent that ties the bond?

The Kolonga Day staged in Auckland was a first for participants. Prevalent criticism from village affiliates was the event was poorly planned. Many Kolonga people - worldwide and not just in Auckland - did not know what was happening, and who was in charge of organising what.

Transmitting information through Facebook pages became the social media mode of interaction with the diaspora, who had greater internet access than Kolonga people living in Tonga. Folks living in the village were reliant on Auckland family members to relay event details by mobile phone or text, and to sponsor visas for those who could afford the return airfare to Auckland for Kolonga Day.

With a population of 1,167 in Kolonga, and an estimated diaspora of 5,000 plus resettled in New Zealand, Australia, and the United States, the major glitch was communication. Kolonga as a global village had no official register that kept an updated record of people's names, ages, and addresses, as well as general population numbers.

The method of contact was still the coconut wireless, a satirical reference to word of mouth. Mobilising village affiliates for Kolonga Day was achieved through an Auckland- 
based organising committee of family leaders. By this, leaders informed respective families of what was going on, and coordinated their tables of food for the feast. Thus, individual family groups were responsible for their own self-catering.

To be expected in a small society, cut-throat rivalry between families outdoing one another for the biggest spread on the table, the most boastful, much to do about nothing speech on the day, and the loudest dance item collecting copious amounts of money, was rife. Noteworthy was that over a third of the attendants were not village descendants, but associates of Kolonga people who more than likely turned up for the food.

As the New Zealand-born daughter of a Kolonga father that migrated to Dunedin in 1966, I gave a speech along with Dr Seini Taufa who was the only other conferred PhD in Auckland with Kolonga ancestry. In total, the village had four doctorates: Dr Feleti Sevele, a geographer and former Prime Minister of Tonga, myself, an anthropologist lecturing at Auckland University of Technology, Dr Tevita Ka'ili, an anthropologist lecturing at Brigham Young University, La'ie, and Dr Seini Taufa, a public health specialist employed at the University of Auckland.

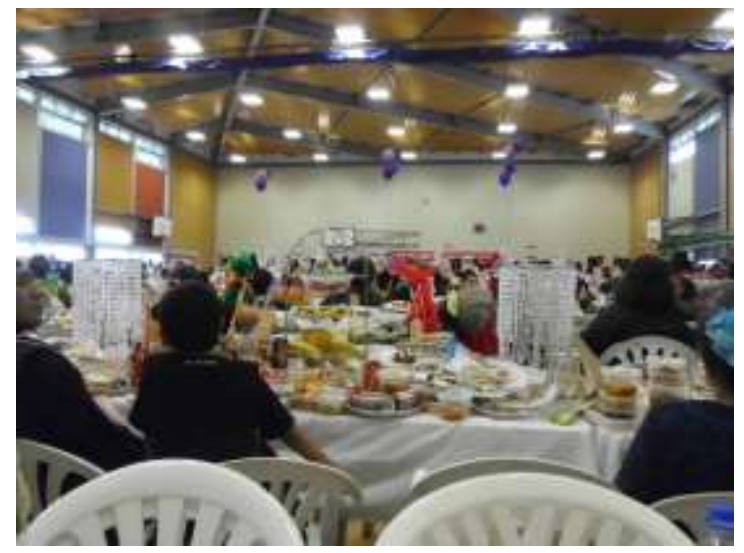

Photograph Credit: Teena Brown Pulu 
My unease was about relevance and practical relationship: how could Kolonga people overseas be useful to improving the "lives and livelihoods" of kinfolk in the village?

If I had one suggestion for future Kolonga Days, it's link the event back to the village in a practical way. I wouldn't want this to be prayer service and feast with no purpose to help Kolonga. Kolonga people live overseas, but the village is a real place with 1,167 residents. What are we doing to improve their lives and livelihoods?

Specifically, I referred to a climate resilience project orchestrated by Nuku, Kolonga's noble and estate holder, myself, an anthropologist, and my father, Semi Pulu, an Auckland council senior building inspector. We sought to have Kolonga made "a coastal community with a special management area under the Tonga Fisheries Management Act, 2002." This resulted in the " 2.4 mile coastline [of Kolonga being] managed, protected, and taken care of by" the village community.

It is absolute myth the foremost anxiety of all Pacific Islanders on planet earth is climate change. The majority of Kolonga people in diaspora, which is the greater number compared to the village population, were unaware of the climate resilience project. Notably, the Auckland-based affiliates gathered at Kolonga Day did not show practical interest by volunteering to fund-raise for infrastructure costs to cordon off, shield, and monitor the village foreshore boundary.

The ancestral village existed in social memory. Migrants held to romanticised memoirs of their origin roots. While their New Zealand-born descendants had little, or no first-hand experience of visiting and staying in Kolonga. What did village day in diaspora amount to in reality? If the truth be told, it was prayer service and feast. 
Tongans at the Otahuhu Leisure Centre scoffing suckling pigs roasted on a spit: how did this help the village back home to survive poverty exacerbated by climate change and intensifying seas? The hard truth was it didn't assist in any way, shape, or form. In Auckland people were fixated with Kolonga Day because of the feasting and showing off, end of story.

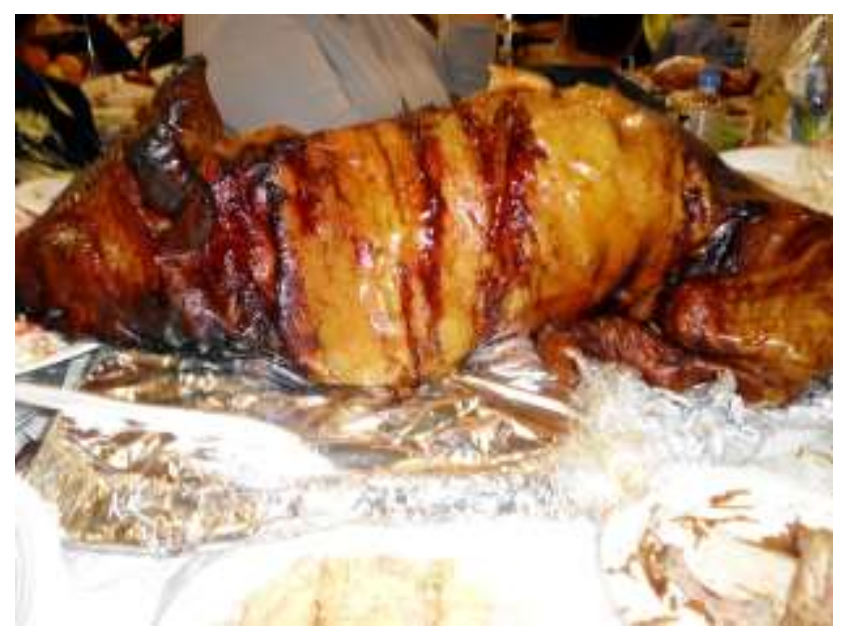

Photograph Credit: Teena Brown Pulu 